\title{
THE SIGNIFICANCE OF 'ANTI IN 1 CORINTHIANS 11:15
}

\author{
Alan G. Padgett
}

\section{Summary}

After discussing two readings of 1 Corinthians 11:2-16 (the traditional view and an alternative) the article explores the importance of a right understanding of the preposition o'vii ('instead of') in verse 15 . It is argued that various lexical choices make no logical difference in this case. Paul is simply stating that nature has given women hair instead of (or, as the equivalent of) a covering. This conclusion adds probability to the alternative reading being proposed.

The overall interpretation of a text will influence our decision as to the meaning and significance of particular words in it. But the opposite should also be true: the meaning of particular words and sentences should influence our interpretation of a text as a whole. This article explores the meaning of a single term in 1 Corinthians 11:15, 'instead of' ( $\alpha v \tau i)$, and its implications for our understanding of the larger pericope.

Scholars have an ongoing puzzlement about Paul's argument in 1 Corinthians 11:2-16.1 There is a wide variety of views as to the meaning of this pericope, and the logic of Paul's argument in it. ${ }^{2}$ I cannot here discuss the many issues involved, but a survey of two possible options for the reading of the passage should serve as a useful introduction to the problem we are focusing on in verse 15.

\footnotetext{
1See A.G. Padgett, 'Paul on Women in the Church: The Contradictions of Coiffure in 1 Corinthians 11.2-16', JSNT 20 (1984) 69-86; cf. G. Fee, The First Epistle to the Corinthians (NICNT; Grand Rapids: Eerdmans, 1987), 493-529.

2I survey some of these options in my article (art. cit.), 73-76; see also Fee, op. cit., 492, nn. 3, 7 for further bibliography.
} 
The traditional interpretation of this passage argues that Paul is imposing a custom of 'covering' on a group of women that were refusing to cover themselves in worship, while praying and prophesying. Paul's argument, on this interpretation, rests on four bases: (1) an argument from 'shame'

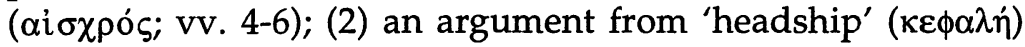
understood as authority (vv. 3-6); (3) an argument from the order of creation (vv. 7-9), and (4) an argument from 'nature' understood as custom (vv. 13-16). In each case, the point Paul is making is the same, according to this majority view. Women should cover their heads in church, while men should have short hair and be uncovered.

A number of holes in the traditional interpretation have appeared in recent years. For example, can the meaning of verse 10 be forced into this mould? Here Paul clearly states the opposite of the traditional view, viz. 'for this reason, woman ought to have control (power, authority: $\left.\dot{\varepsilon} \xi_{0} 0 v \sigma i \alpha\right)$ over her head'. The normal interpretation is that the covering is a 'symbol of' authority 'on' her head, but such an interpretation cannot withstand careful examination. ${ }^{3}$ Moreover, he goes on to summarise: 'in any case, woman is not independent of man, nor man of women, in the Lord. For just as woman came from man, so man comes from woman, and all people come from God' (vv. 11-12). Is Paul contradicting himself in this passage?

Of course, Paul may have simply been confused at this point, or grossly misunderstood. In defence of the latter claim, Dr. Katherine Bushnell argued as early as 1910 (correctly, in my view) that in fact some Corinthians wanted to impose this covering on women's heads in worship. ${ }^{4}$ This interpretation takes its

${ }^{3}$ See Padgett, art. cit., 71f.; Fee, op. cit., 518-522.

${ }^{4}$ K.C. Bushnell, God's Word to Women (3rd. ed; Oakland, CA: private, 1930) par. 240-249. I am grateful to Fee for pointing out to me the similarities of my view to Bushnell's. The first edition of this work was published in England as a small pamphlet (Southport: Lowes Ltd., no date). Both Fee (op. cit., 493) and the National Union Catalogue seem uncertain as to the original date of this pamphlet. The Bodleian Library, Oxford received their copy on April 14, 1910. So the first edition should be dated 1910 . 
cue from the polemical nature of 1 Corinthians. ${ }^{5}$ Paul is not imposing a cultural norm on Corinthian women. Instead, he is paraphrasing the argument of some Corinthian faction in verses 3-7. He then argues against them, beginning with 'but on the other hand, woman is the glory of man' (v. 7c) and so through the rest of the passage. The fact that woman is created out of man, and because of his 'not good' situation, is seen in a positive light, as evidence of her being the glory of man (vv. 7c9) On this view, the sentences in verses $14-15$ are understood as statements, not (following the traditional view) as rhetorical questions. Indeed the earliest translation (the Vulgate) reads these verses as statements, not questions. ${ }^{6}$ In the same vein, the three-part 'headship' formula of verse 3 is understood to be Corinthian in origin.

A structural parallel to Paul's argument at 11:2-16 is found in $8: 4-13$. In that chapter, Paul begins by citing the slogans of the Corinthians (8:4) and then proceeds to paraphrase their views (8:5-6). He then corrects and opposes their theological justification for eating meat sacrificed to idols (8:713). What becomes clear from both cases is this: the boundary of thesis and antithesis in 1 Corinthians is not marked by clues in the grammar or punctuation alone, but by the give-and-take of the argument itself.

Which of these two interpretations is correct? Perhaps both are false: more analysis, exegesis, and dialogue is called for concerning this passage. I hope to contribute to this larger task, by considering the function of $\alpha v \tau i$ in v. 15. The phrase in question reads:

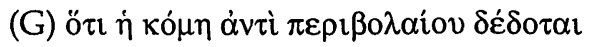

In the light of the passage as a whole, it is clear that 'nature itself' (v. 14) is doing the giving in this phrase, and it is woman

${ }^{5}$ M.M. Mitchell, Paul and the Rhetoric of Reconciliation (Philadelphia: Westminster/John Knox, 1993) came across my desk too late to be incorporated into this article. However, her suggestions concerning 11:2-16 would support the alternative reading I am arguing for, against the traditional view.

6I owe this point to the Rev. Dr. Richard Sturch. 
that is receiving. So we can paraphrase an English translation of $(\mathrm{G})$ as follows:

(E) For nature has given woman hair anti a covering.

In order to avoid begging the question, I leave the word anti untranslated in $(\mathrm{E})$.

Like the English words 'for' and 'as', the preposition $\alpha \dot{\alpha} v i$ has a wide semantic range. Our modern confusion over Paul's use of $\alpha \dot{v} \tau i$ in $(G)$ can be illustrated by the recent UBS lexicon. ${ }^{7}(G)$ is translated twice in this lexicon, once as 'her long hair has been given her as clothing' (par. 6.163), and once as 'her hair has been given to her for a covering' (par. 8.14). Yet in their discussion of the word óvii, neither 'for' nor 'as' appear at all!8 Simply listing 'for' or 'as' as a meaning is not helpful, since both of these English prepositions have very wide semantic ranges. We need to examine carefully the semantic range of the Greek preposition to understand Paul's argument.

What possible uses, then, could Paul have been putting this word to in (G)? From LSJ (s.v. $\dot{\alpha} v \tau i$, section A.III) three possible uses can be considered:

(1) 'instead of,'

(2) 'as the equivalent of,' or 'to serve as,'

(3) 'in exchange for,' or 'as substitute for.'

BAGD gives virtually the same list of possible uses. ${ }^{9}$ In his recent commentary, Gordon Fee correctly calls attention to the variety of uses $\dot{\alpha} v \tau i$ can have in Greek, against a number of scholars who have assumed that 'instead of' is the obvious meaning. ${ }^{10} \mathrm{I}$ am grateful for Fee's discussion of my views, and I wish now to modify my earlier assertion that 'for use as' lies outside the semantic domain of this preposition. ${ }^{11}$ Against my

7J.P. Louw et al. (eds.) Greek-English Lexicon, 2 vols. (New York: UBS, 1988).

'See the index to Greek words, Vol. 2, p. 22.

9I take it that 'on behalf of' (BAGD, s.v., section 4) as a meaning for $\dot{\alpha} v \tau i$ here is ruled out by context; this leaves us with the above three possible uses.

10Fee, op. cit., 528.

11Padgett, art. cit., 82. 
earlier view, 'for use as' is a possible translation of $\alpha v \tau i$, when what is meant is the idea of substitution or equivalence.

The closest that one might come to 'for use as' in the semantic domain of 'ovti would be something like 'serve as' or 'just as' in the list of citations given in LSJ (A.III.2). Some cited passages could just as easily have been listed under 'instead of.' 12 An interesting and clear classical use of $\alpha \dot{v} \tau i$ in the sense of 'just as' is found in an oration attributed to Demosthenes, in a passage describing a hypothetical return of despots to Athens: 13

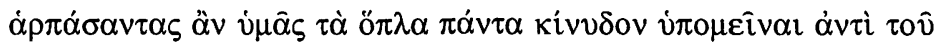

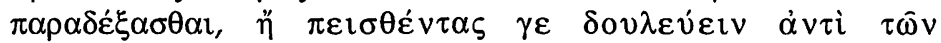

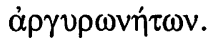

The dual use of $\dot{\alpha} v \tau i$ in this case is an example of rhetorical artistry. In the first use, the sense is the normal one of replacement ('you would remain steadfast in the face of danger rather than accept them back'). The second occurrence is the one that interests us. Here the idea of replacement will not do, and the sense is that of 'just as' or equivalence ('to serve just like slaves'). This may very well be how Paul uses the preposition in $(G)$, as Fee thinks.

Fee asserts that it is important for his view that (2) can be the use Paul makes of $\alpha$ ví in 1 Corinthians 11:15:14

[T] here is no need to force the rigid concept of replacement onto this sentence...Paul is arguing by analogy that since women have by 'nature' been given long hair as a covering, that in itself points to their need to be 'covered' when praying and prophesying.

Yet Fee is surely confused at this point. In meaning (1), (2) and (3) are surely different, but in context the choice between them

\footnotetext{
12For example, Herodotus, Histories 4.75. The idea of replacement in this text is made obvious by the context. Speaking of the steam-baths

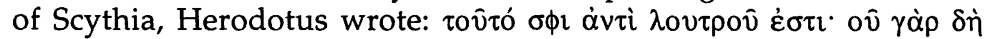

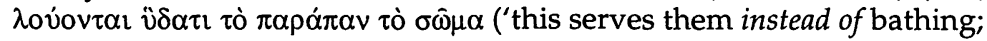
for they never wash their complete body with water').

${ }^{13}$ On the Treaty with Alexander 3.

${ }^{14}$ Op. cit., 529.
} 
makes no difference in the argument as a whole. In this sense, I will argue that the difference between these possible uses or meanings is not significant in the context of Paul's argument.

That it makes no logical difference which option we choose can be brought out by inserting these different phrases in our translation of $(\mathrm{G})$ :

(E1) For nature has g:ven woman hair instead of a covering;

(E2) For nature has given woman hair as the equivalent of a covering;

(E3) For nature has given woman hair as substitute for a covering.

Paul is arguing with the Corinthians about a covering of some kind for women's heads during the worship service. The exact nature of this 'covering' will not detain us now. But I see little logical difference in Paul asserting that by nature women have hair instead of a covering (E1), and his asserting that hair is, for women, the equivalent of the covering in question (E2). If nature gives us $A$ as the equivalent of $B$, then what we have is $A$ rather than having its equivalent (i.e., B). In other words, we have A instead of B. Indeed, although (E3) is an unlikely possibility, it too makes that same point: in their natural state, women do not have this 'covering'; instead, as a substitute for such a covering nature has given women hair. The point being made is exactly the same, no matter what translation we adopt. Thus by nature women have hair, as a substitute for a 'covering.' So in context (E1), (E2) and (E3) are equivalent for the purposes of Paul's argument.

To make this fact plain, consider the following illustration. You come by my office, asking for a dollar bill. I give you four quarters. This could be understood in three ways. I give you four quarters 'instead of' one dollar; or I give you four quarters 'as the equivalent of' one dollar; or I give you four quarters 'as substitute for' the dollar bill, or 'to serve as' a dollar bill. The meaning of these sentences is surely different. But the basic point is the same. The same thing can be said of our different interpretations of (G) in (E1), (E2), and (E3). These sentences mean different things, but they make the same basic point. 
The point Paul wants to make in verse 15 is obvious, once the meaning of the preposition is clear. Paul asserts that women already have the equivalent of a covering, namely hair. So surely women don't need another covering on top of the one nature has provided! Pace Fee there can be no 'analogy' between verse 15 and verses $5 b-6$. Thus, not only does Fee miss the fact that there is no logical difference between (E1), (E2) and (E3); he states that there is an analogy where in fact none exists. He asserts that verse 15 is the 'Achilles' heel' of other views of this passage, 15 when in fact it is a weak spot in his own.

My point is a simple one. Fee makes too much of a difference between (E1) and (E2) which is there at the exegetical level, but which makes no difference to the argument. He asserts that there is an 'analogy' between verse 15 and verses 5-6, when in fact what we find is a contradiction. The argument in verses 5-6 implies that women need a covering of some kind, while verse 15 implies that they do not; instead they have its equivalent (i.e., hair).

What is the significance of this fact? Simply this: it makes the traditional reading of the passage less likely. Why would Paul impose a covering in 11:3-7b which he then admits women don't need in verse 15 (and also in vv. 10-12)? On the alternative view I am suggesting, verse 15 does make good sense in the light of the passage as a whole: in their natural state, women do not need a 'covering,' since nature has given them hair as the equivalent of a covering. This is just one more reason the Corinthians should not insist on women wearing a covering in worship. However, to demonstrate that such a view is the most likely one, against Fee's other criticisms, would take us beyond the scope of this short note. 16

${ }^{15}$ Op. cit., 529.

16I should like to thank Drs. Mark Reasoner, Bruce Winter, Gordon Fee and especially Mike Holmes for comments on earlier drafts of this essay. 